\title{
Utilizing the New Technologies For Enhancing Healthcare Tourism in Egypt
}

\author{
Dr. Khaled Mohamed Sadek Mohamed \\ Program Business Information Systems, Faculty of Commerce \& BA, \\ Helwan University, Egypt
}

\author{
Omar Salman \\ Professor of Business Administration \\ Helwan University
}

\begin{abstract}
This paper recognizes and identifies various new advances technologies and applications in Information Communication Technologies that gradually revolutionize the tourism industry and related business and industries.
\end{abstract}

The Tourism business sector is the most aggressive and competitive business in the worldwide and one of the most complicated business sectors .The tourism industry primarily consists of businesses that provide accommodation, transformation, flight trips, attractions, food and beverage, and integrated combination of these activities.

This research is focused on using the new technologies to develop healthcare tourism in Egypt by increasing the tourist awareness of healthcare tourism. This aim is achieved by using new technologies such as Big Data Analytic Technology and knowledge-based information system in order to forecast tourist's demands, needs and requests in tourism industry sector. Any data concerning the future development of tourism flows is of extraordinary significance to hoteliers, travel agents and other industries related with tourism business.

Precise prediction of traveler services needs will be coordinated for the business' activities and allotment of assets, for example, labor, money related administration, advertising the executives... and so on to accomplish adequacy of arrangement ahead of time and cost decrease. Showing that the Internet and sharp technological development have encouraged the increasing demand for tourism and using new technologies in forecasting the tourist demands and needs will naturally promote or potentiate an increase of tourism demand.

Keywords:- Information and Communication Technologies, ANNs, big data analytics, Tourist's Demands and needs, healthcare tourism.

\author{
Ibrahim Elhenawy \\ Professor of computer sciences \& information systems
}

\section{INTRODUCTION}

Information Technology is playing a significant job in the travel and tourism industry in many ways as helping in costs reduction, operational efficiency enhancement, and improvement of services and customer experience.

Technological development and advancement have been continually impacting the travel industry and travel industry. The Internet and related advanced advances are impacting the entire tourists venture for the two visitors and tourism professionals alike. The manner in which travelers get motivated, book, plan and experience travel has changed (Neuhofer et al., 2012) in addition, the necessity for the travel industry publicists to develop new models to progress and market their objectives has been made (Huang et al., 2012). One of the vital contemporary technological developments impacting the tourism segment is Virtual Reality (VR) (Tussyadiah, et al., 2017), it is a computer simulated sites that enables the travelers watched their experience it virtually (Desai et al., 2014).

Both tourists and travel agents can profit by improved communication, reservations, and guest service systems. The new technologies have helped tourism industries supplanting costly human work with technological labor. This is not just aiding in lessening work costs, yet additionally staying away from client support issues.

Egypt has amazing natural sites throughout the country and has assorted vacationer assets that have corrective capacities with the ability of giving a wide assortment of the best clinical the travel industry goals with wellbeing and normal materials in Safaga and the desert garden of remedial desert springs in Siwa and Dakhla .

Also, healthcare, and medical tourism based on natural and modern resources has led to attract many medical tourists from various nations.

Information and communication technologies have been confirmed, as they increase efficiency, productivity and improve overall business performances through some of new technologies and applications such as Artificial Neural Networks (ANNs), expert systems, GPS, smart phone communication and Big Data Analytics. 


\section{TOURISM INDUSTRY WORLDWIDE}

Tourism industry is portrayed as 'all the human's activities of individuals going to and remaining in places outside their homes for voyaging relaxation, business or various purposes for not more than one successive year' (Go2hr, 2016). The travel industry is as one of the quickest making adventures on the around the world.

Over the earlier decades, tourism has encountered proceeded with improvement and expansion to end up one of the biggest and quickest developing financial and economic sectors 2017 was a record year for universal tourism. Universal tourist arrival developed for eighth year, a grouping of continuous development not recorded since the 1960s. Destinations overall invited 1,500 million worldwide vacationer entries, about 84 million more than in 2016.

International tourist arrivals have expanded from 809 million globally in 2005 to 929 million in 2008, 995 million in 2011,1133 million in 2014, 1,323 million in 2017 and 1500 million in 2019.

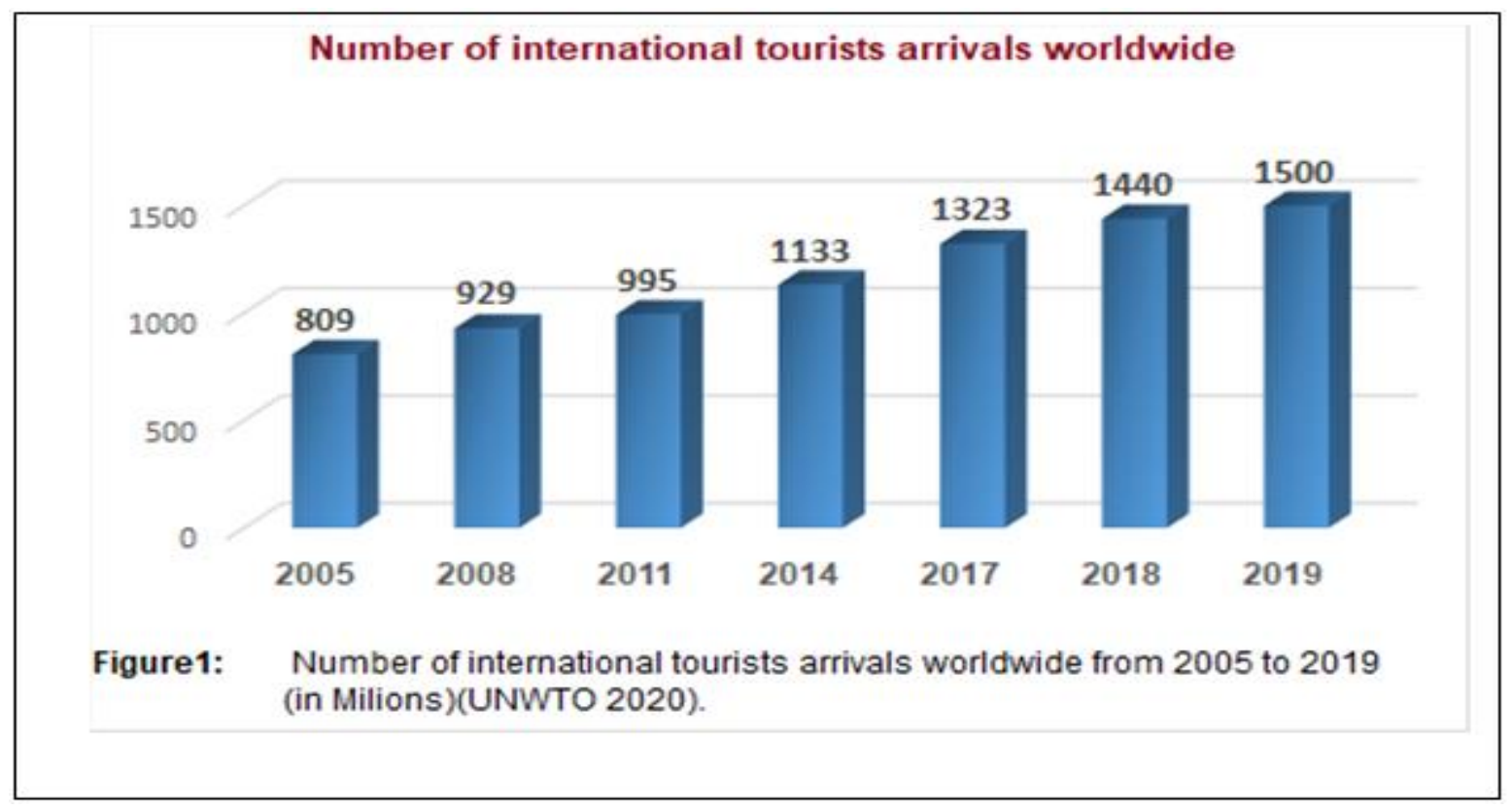

The tourism industry sector as first one of the world's biggest monetary sectors, Travel \& Tourism industry makes human jobs, developed related industries, exports, and produces success over the around the world.

Global tourism industry receipts earned by objectives worldwide have flooded from US\$2 billion out of 1950 to US\$ 104 billion of each 1980, US\$ 495 billion out of 2000, and US\$1.649 Trillion out of 2019.

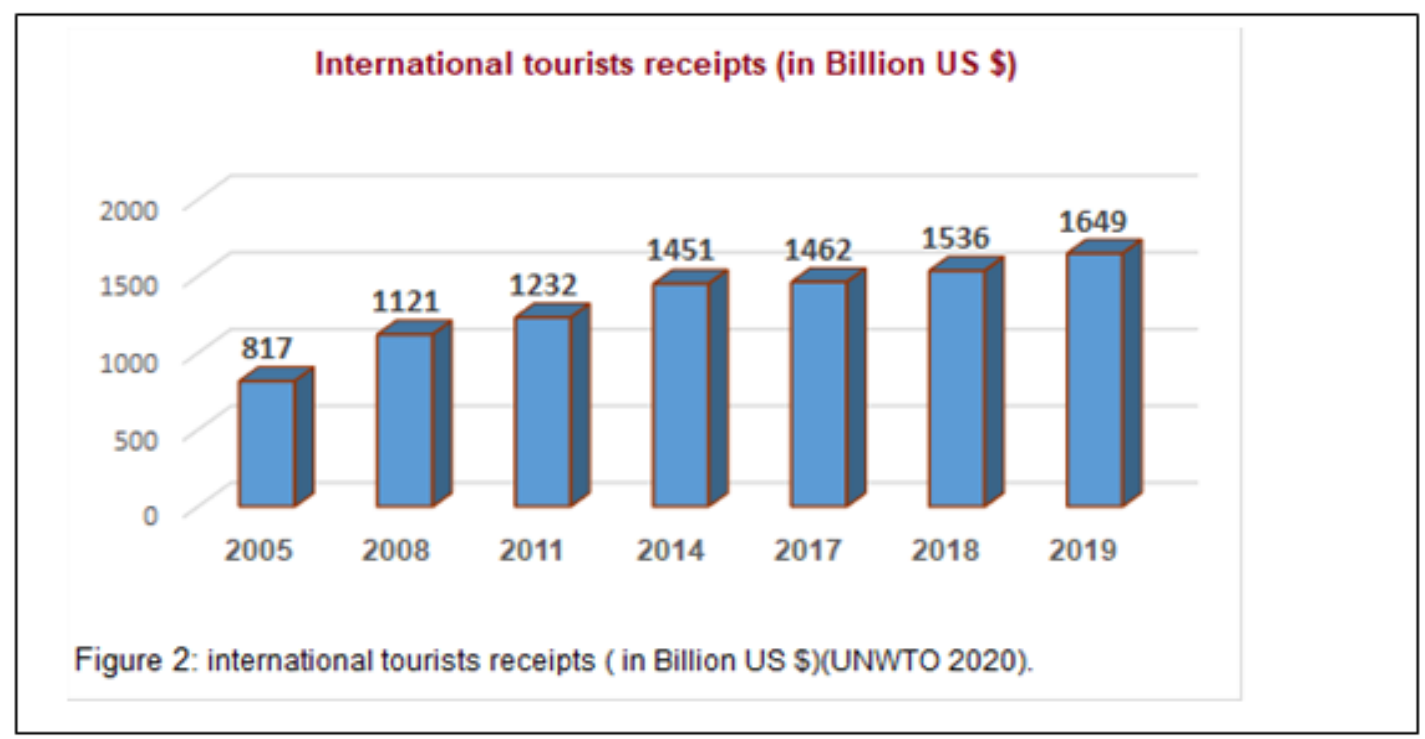


As one of the world's greatest monetary parts, Travel and Tourism create employments, sway in more fares, and delivers thriving over the around the world. In UNWTO 2020 report examination of the overall monetary impact of the Tourism business area is seemed to represent $10.4 \%$ of overall GDP and 319 million occupations, or $10.4 \%$ of all out work, in 2018.

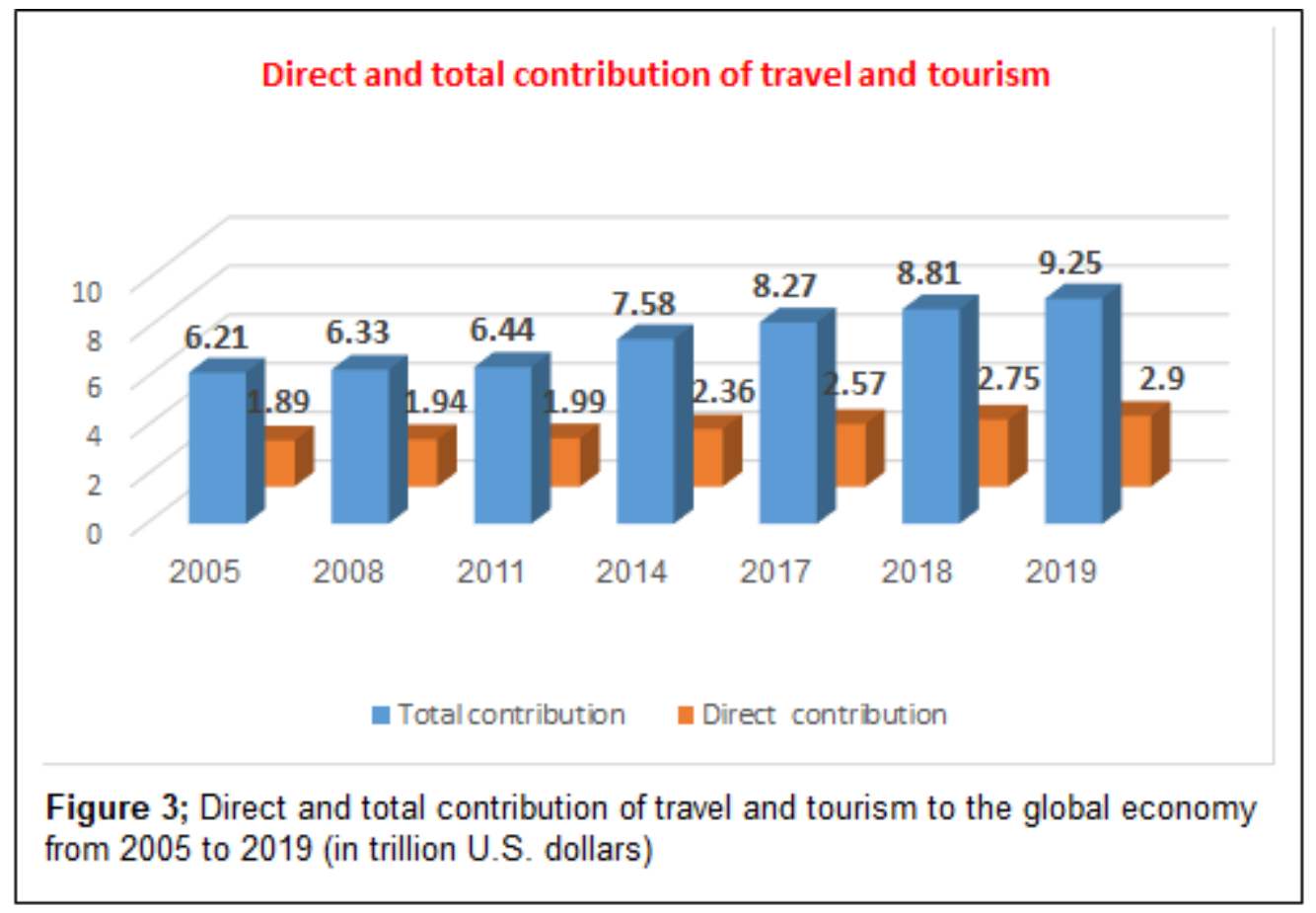

Sustainable tourism: It is characterized as tourism industry that depends on the essential components of nature such as the sea, ocean, forests, desert, archeology and old culture, without these elements the tourism capability potential of an area would be limited.

Sustainable Tourism industry includes having a base human effect yet enough human movement for a venture to finance itself which can augment both the monetary just as the social salary, while constraining any antagonistic effect on natural, social inheritance and social legacy at the meantime.

The year 2017 was an exceptionally critical one for the worldwide tourism network. In 2015, the United Nations General Assembly reported 2017 as the International Year of Sustainable Tourism for Development, an overall affirmation of the travel industry's groundbreaking responsibility to the turn of events and improvement plan. The exercises and events that happened all through 2017, in the arrangement of the International Year, served to more bring issues to light worldwide of the supportable part's capability to lead monetary turn of events, social incorporation and social, natural protecting and ecological conservation (World Tourism Organization Annual report 2017).

Through online proposal portal can forecast tourists needs and perceive purchasers as a method of making and offering just as having the option to screen and moderate the talk, taking on business and administration over themselves and its approach to changing the movement business, yet not by making a totally new undiscovered wilderness, however by giving customized and upgraded choices to every client, bringing down the vulnerability of movement, expanding the trust about goals and benefits, and creating information for organizations to actualize more helpful, productive, and reasonable administrations.

\section{TOURISM INDUSTRY GROWTH AND DEVELOPMENT IN EGYPT}

Tourism industry is one of the principle wellsprings of the national pay in Egypt and that is the reason the state is quick to advance and build up this significant industry. Thus, the administration has taken a few measures to serve this division and different segments also.

The value for International tourism number of travel arrivals in Egypt was 14.1 million as of 2010 and the number of travel arrivals in Egypt was 13.6 as of 2019.

13.6 million Visitors came to Egypt in 2019. This imprints 54 percent expansion in the quantity of tourists contrasted to 2016, the jump in tourist quantity last year helped tourism incomes by 123.5 percent year-on-year to $\$ 12.6$ billion. 

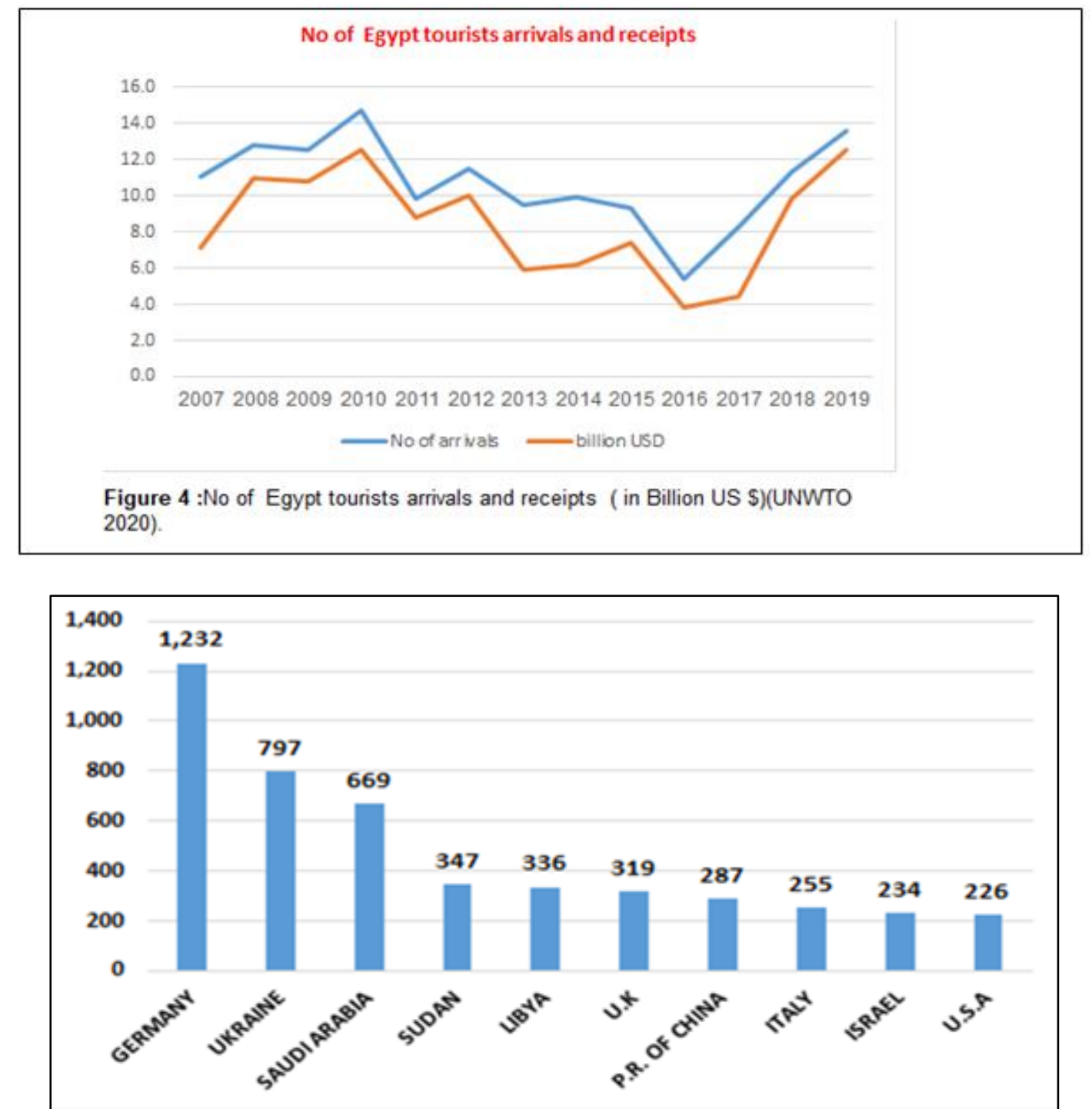

Fig 5:- Egypt Top Ten countries CONTRIBUTION in 2017 'Nights' resource (Egyptian Tourist Authority Information Center 2018).

\section{Egypt - tourists Per Market in 2019 (Thousand)}

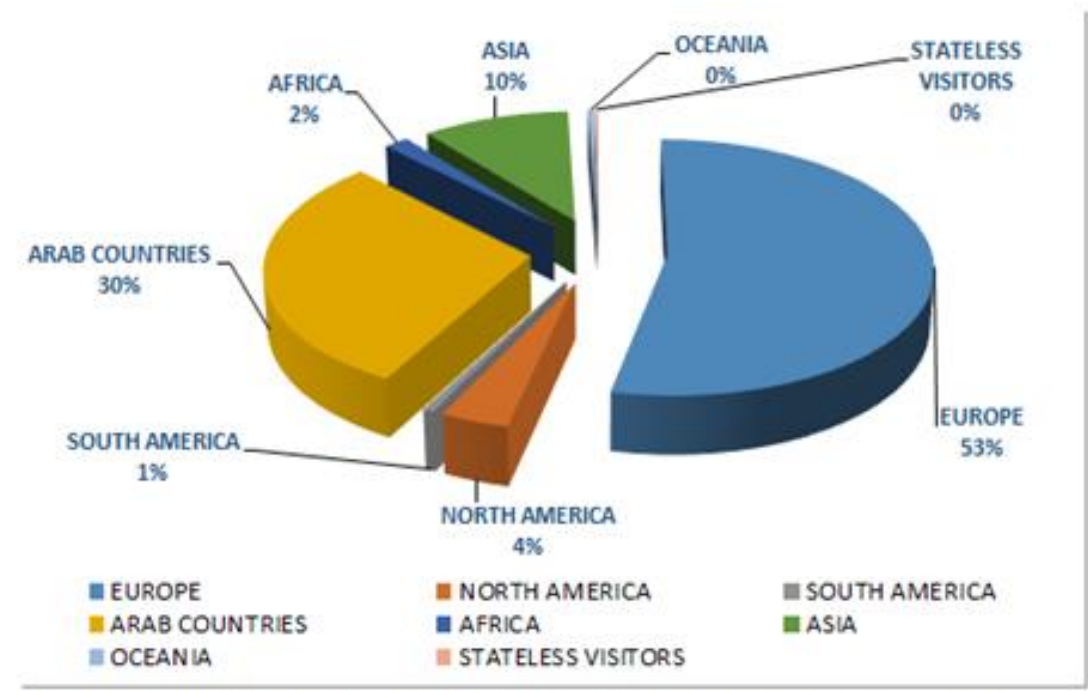

Figure 6: Egypt - tourists Per Market in 2019 "Tourists" resource (Egyptian tourist authirity information center 2020). 


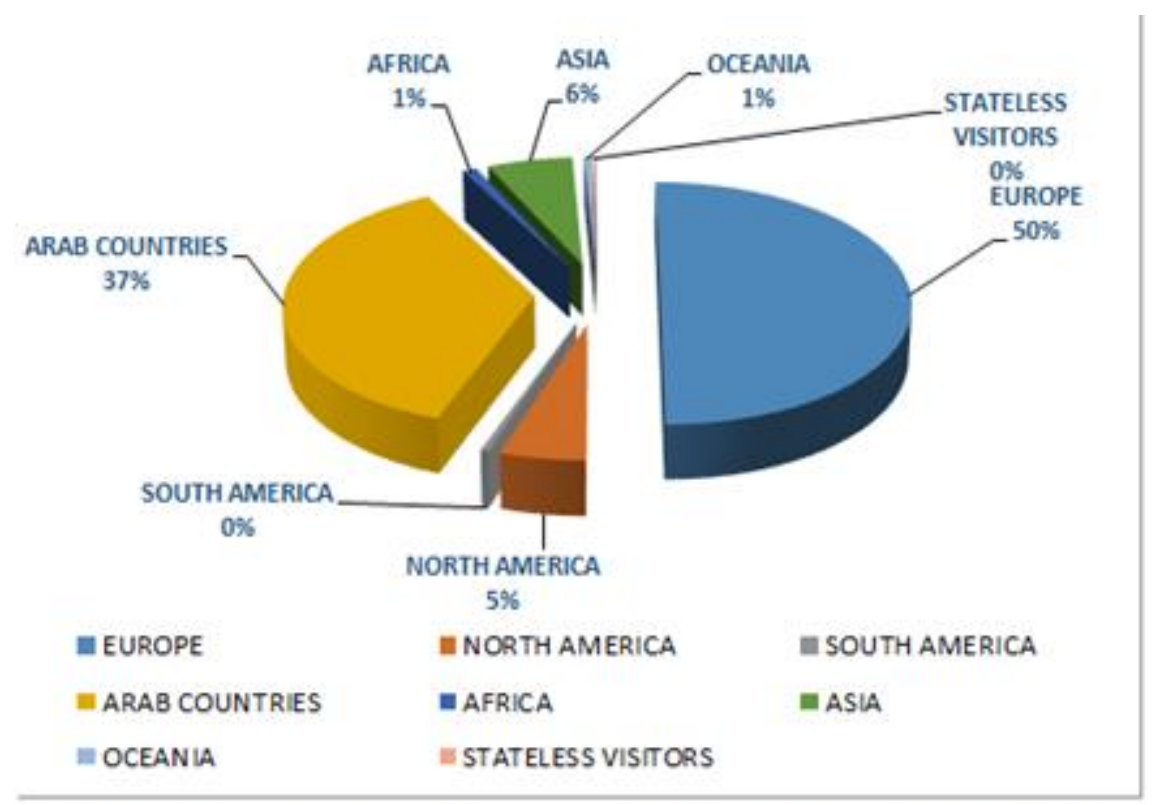

Figure 7: Egypt - tourists Nights per Market in 2019 "Tourists" resource (Egyptian tourist authirity information center 2020).

Egyptian tourism industry has just accomplished its most noteworthy ever the travel industry income in 2019 the UN World Tourism Organization (UNWTO) positioned Egypt as the fourth quickest developing goal on the planet; with another rundown of insights as of late distributed, information uncovering that Egypt's travel industry segment saw an incredible development of 21 percent through the span of a year ago - that is 13.6 million guests.

\section{The Egyptian sustainable tourism destinations:}

- Medical Tourism and Youth Renewal: Egypt offers best clinical the travel industry goals with wellbeing and characteristic materials in Safaga and the desert garden of helpful desert springs in Siwa and Dakhla. Just a few hours from the fuss of Cairo, the environment of Siwa desert spring is agreeable, with streams and serene nurseries mixing with conventional nearby culture. Encircled by great organic product Farms, Dates and olive trees and gardens, going back to the hour of the Pharaohs. These and other pick goals in Egypt advance health and recharging through accommodating remedial sand, rich mineral water for skin and body care. In less regular, Egypt has become the popularity of medical tourism is growing with Arabs and Europeans searching for high caliber, Affordable costs beauty care products, settlement expenses and attractions.

- Environmental sites: Egypt has amazing natural sites throughout the country, such as the Sinai Peninsula, Western Sahara, Eastern Province, oases and Fayoum, just as radiant seashores, including the desert Landscapes, desert gardens, valleys and cascades. The special Eastern and Western desert in Egypt offers some of them from the most well-known desert safaris on the planet, while trips over the sands The Sinai Mountains are a chance to investigate untamed life and one of a kind natural locales, including frosty lakes and olive forests. The desert springs situated toward the west of the Nile.

- Beaches and Resorts: Egypt has a sunny weather throughout the year, and has a wonderful underwater life, with the nearest coral reefs to Europe off the Sinai Peninsula in the Red Sea. The northern coast draws in Arab, European, and East Asian vacationers with a domain like southern Greece, Italy and Spain. From tourism towns in the Red Sea is home to dive destinations on the planet. And seeing protected coral reefs, good visibility, scuba diving and rich diversity, White coral sharks, solid and soft coral reefs, sea turtles, snakes, and angel fishes.

- Historical sites: Ecological destinations: Egypt has astonishing common locales all through the nation, for example, the Sinai Peninsula, Western Sahara, Eastern Province, desert springs and Fayoum, just as radiant sea shores, including the desert Landscapes, desert gardens, valleys and cascades. The special Eastern and Western desert in Egypt offers some of them from the most wellknown desert safaris on the planet, while trips over the sands The Sinai Mountains are a chance to investigate untamed life and one of a kind natural locales, including frosty lakes and olive forests. The desert springs situated toward the west of the Nile. The Roman vestiges are referenced in the northern beach front city of Alexandria with Egypt's assorted foundation. Khan el Khalili is one of the most settled bazaars roads on the around the world. Investigation destinations all through the nation keep on revealing proof of Egypt's rich legacy. 
- Religious sites: Strict the travel industry has extended constantly throughout ongoing years. A champion among the most standard objectives is the Monastery of St. Catherine in the Sinai Peninsula, and furthermore the area of the consuming shrubbery of Bush. Vacationers can likewise follow the way of the Holy Family in Egypt. The religious community of St. Virgin was worked close to a cavern where the Holy Family is accepted to have been halted. The priests despite everything sort out day by day visits to the cavern and festivities close to the site. Back in the capital, sightseers can visit Coptic Cairo and Islamic Cairo in Al-Moez and Al-Gamalya Street and furthermore the Islamic the travel industry of the Buhara family, where they can visit a portion of Egypt's most established Christian and Islamic strict destinations, including the Hanging Church. The capital is additionally home to significant mosques

\section{HEALTHCARE TOURISM}

Healthcare tourism takes place when tourists choose to travel across national borders with the aim of receiving medical treatment. The possibility of medical treatment the travel industry isn't new paying little heed to what number of are the wellsprings of data that manage its amazing turn of events and association which could prompt think as though it was another marvel. Notwithstanding, Medical the travel industry dates to as old medication. According to certain sources (Kajzar, 2015) wellbeing the travel industry as a rule is a term used to allude to either ailment or clinical the travel industry and health the travel industry exercises. Sickness the travel industry incorporates venturing out to improve and recoup the prosperity of the traveler. Along these lines, clinical registration, cardio or neuron medical procedures, dental and joint medicines are the clinical methodology that require qualified clinical mediations Furthermore there are medicines for instance spas, warm or knead, needle therapy, diet or magnificence care, home grown and home-treatment or yoga treatment which are viewed as wellbeing the travel industry (Ahwireng-Obeng and van Loggerenberg, 2011).

\section{$>$ Types of Healthcare Tourism:}

- Medical tourism: It centers on around medicine and healthcare treatment like surgery and pharmacological intercessions. It offers a state-of-the-art healthcare through services providers like clinics, hospitals Medical analysis laboratories, Radiology Centers, and diagnostic centers.

- Medical wellness tourism: it centers around on getting the balanced between medical services and tourism industry. The result is a harmony between medical treatments, recuperation programs. Medical wellness programs are provided in spas and resorts under experts' medical supervision. Programs usually address issues like weight reduction, stress treatment, body detoxification, thalassotherapy by utilize use of seawater in restorative and health treatment and fragrance-based treatment by using the natural oils to improve psychological and physical well-being.
- Wellness tourism: It focuses on improving the "feel good state by rejuvenating the physical and spiritual state of customers using approaches like body pampering like herbal bath, mud bath, beauty treatments and exercise programs. Those activities could be offered by a department at a resort or a spa in the metropolitan areas.

\section{$>$ Tourism of Natural Therapy in Egypt:}

The health tourism industry in Egypt from a long time depended on natural components and is considered one of the richest environments where there are natural elements of interest where Egypt Zones famous mineral waters and sulfur dry atmosphere free from moisture and soil of sand and silt in favor for the treatment of numerous maladies, and the assortment of its shorelines, Hot Eyes water and water seas, with its unique natural properties. Egypt have all the components of a health tourism industry. Weather, the geography's location in the middle of the world, Reasonable prices for both in healthcare site and tourism activities, an extensive variety of services at integrated medical centers, and healthcare professionals with international education and training should make Egypt a favorable greet destination for many people from all the world.

Egypt offers the best Natural Therapy tourism destinations with health and natural materials because it is rich with Natural Therapy in different places, each with special environment and it is normal assets as right treatment against various illnesses, diseases type which can be well treated there. Like example:

- Safaga city: Safaga city is the main goal in Egypt for the treatment of psoriasis and also cure a number of other skin diseases and rheumatoid arthritis. It is located $53 \mathrm{~km}$ south of Hurghada on the Red Sea and it has become, over the past years, a world-renowned destination for Natural Therapy, Safaga black sands: The Laboratory analysis have shown that $40 \%$ of Safaga sand comprises of three radioactive components existing in moderate focus in low-power non-poisonous portions: uranium, potassium 40 and thorium, and Other components, for example, salts, particularly the gold salt, and minerals are successful in rheumatoid treatment. This clarifies the intensity of the Safaga sand to fix rheumatoid patients and the individuals who experience the ill effects of different joint infirmities. Individuals experiencing illnesses, for example, psoriasis and rheumatoid joint inflammation, Safaga the sea water: in Safaga the ocean water is exceptionally salty, containing $35 \%$ more salt than different seas and oceans: treatment with this water can create a major enhancement in the circulatory framework, subsequently expanding the stream of blood to all human body parts and the limbs and skin. The safaga sea water has been appeared to give noteworthy lightening to sufferers from psoriasis and the high thickness of bright beams in the region additionally helps fix various other skin ailments. 


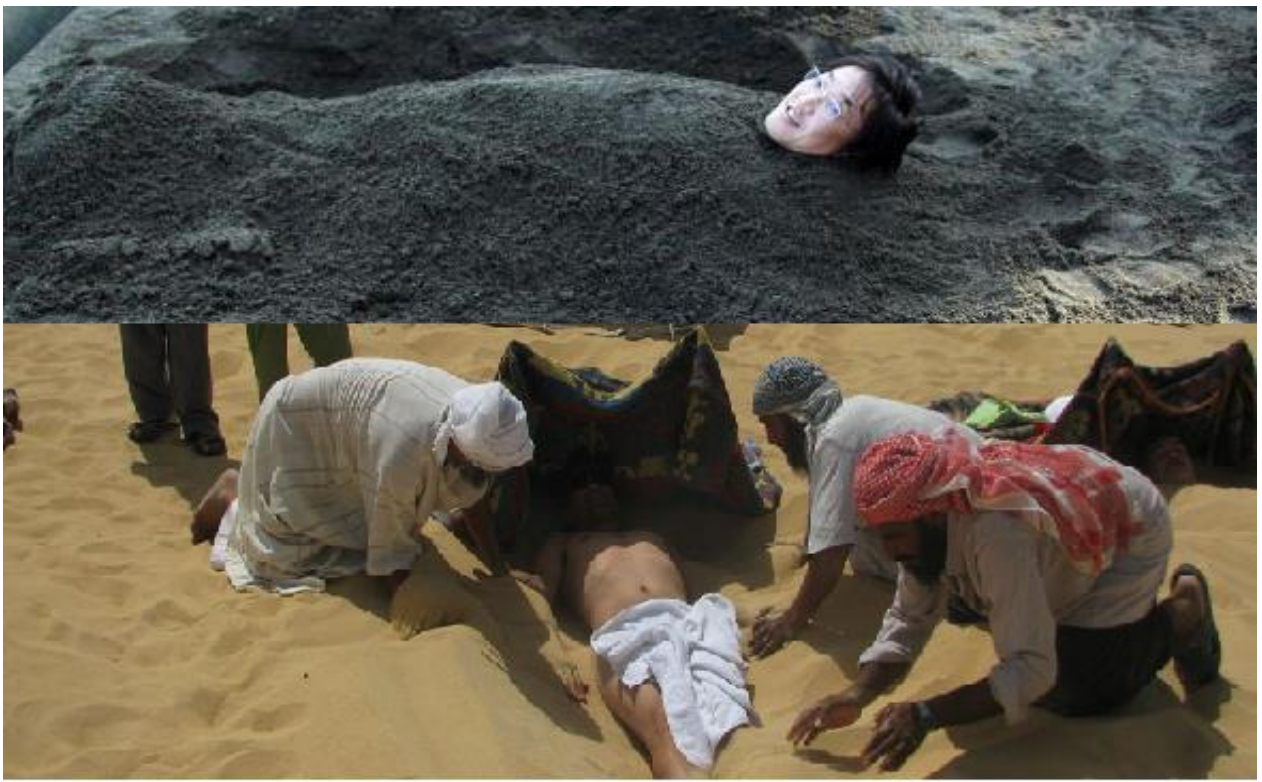

Figure 8: $\quad$ Treatment by of burial in the sands of Safaga

- Aswan city: Aswan, Egypt sunniest southern city Aswan city located in the eastern bank of the Nile Upper Egypt, around 899 kms south of Cairo., around 81 miles south of Luxor, it's a well-known winter resort on the planet, with its all year dry climate and clear sky which ensures a serious degree of bright shafts in the light.

This climate is especially appropriate for patients experiencing kidney and respiratory issues and also for people with rheumatism, it's one of the beautiful cities in Egypt and famous with many tourisms attractive sightseeing especially Pharaonic landmarks in the other hand it is a perfect beautiful place to relax and exploit advantage of the fantastic natural curing features of Aswan's climate and natural curing properties of Aswan's climate and environment. Aswan has been known for its natural treatment: covering the aching parts of your body in sand gives significant outcomes and can help lessening you from obstinate illnesses, for instance, stiffness, joint aggravation, joint edema and skin disturbance, there are focuses in Aswan that have practical experience in medicines utilizing dark sand and water treatment by entombment in sand happens in the spring and summer seasons between the months March and October, when the sun pillars are solid. In the Isis Island the state of rheumatics is incredibly improved when they experience day by day drenching in the mud of the island for three back to back weeks, and are likewise presented to the bright beams reflected from the mountains encompassing the Island and from the water of the Nile.

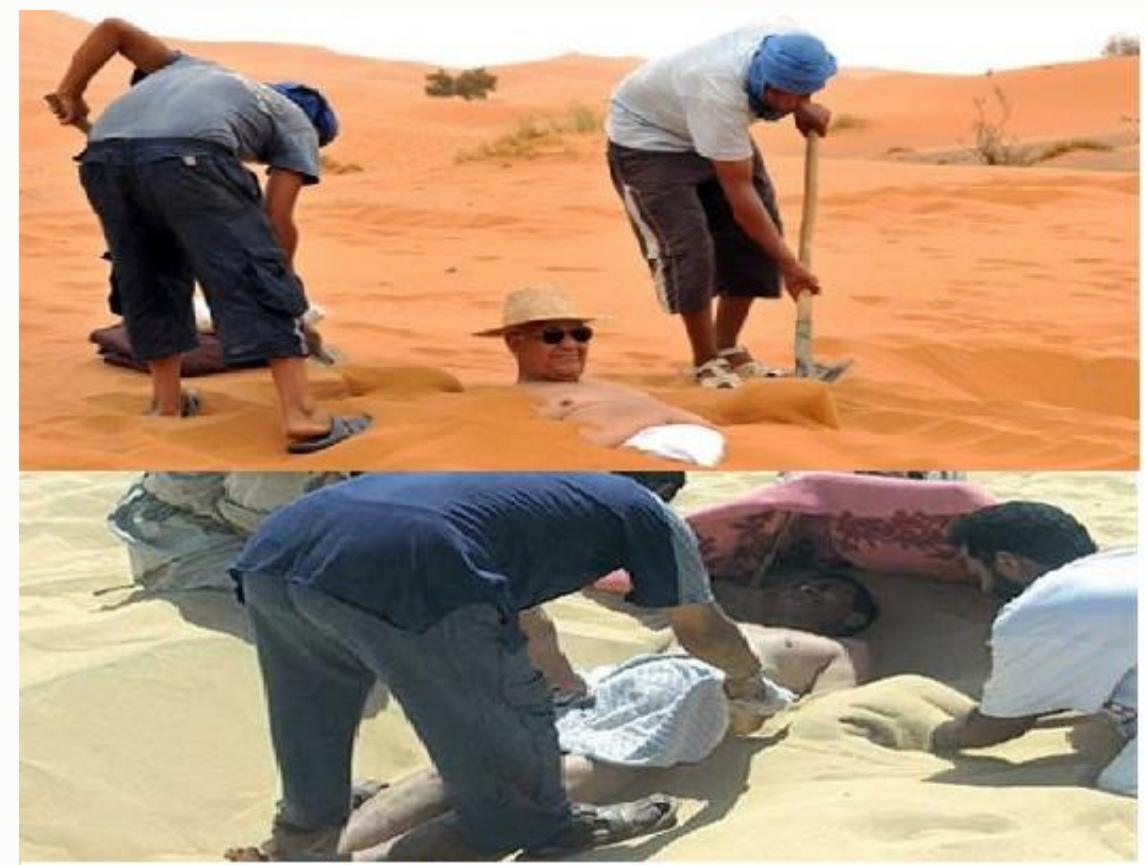

Figure 9 : The burial in sand in Aswan City 
- Siwa Oasis is situated in the western desert, 300kms toward the west of Marsamatrouh North drift and $800 \mathrm{Km}$ from Cairo. It is Egypt's natural healing centers and occupies the forefront among the best places for medical tourism and natural healing in Egypt this is doubtless the most attractive to the tourist, with its mild temperature, unpolluted air and clear blue sky Situated in the south-east of the Siwa Oasis the Siwa sacred mountain Gained the mountain when people since time immemorial therapeutic importance in rheumatic diseases, joint pain and a general feeling of weakness and debility. The treatment the specialize in burying the body with sand for periods ranging between a quarter and a half hour a day on a fourteen day extend in the summer months amid specific hours of the day. Notoriety has been shot to this type of environmental treatment until he became famous Mount Dakror destination for medical tourism, frequented by tourists from all the world. in siwa Oasis spread a mineral water utilized Physiotherapy from a few illnesses, for example, psoriasis and gastrointestinal sicknesses and rheumatic ailments. The most celebrated of these eyes, the most well-known of these eyes, and the most important of all wells Chegar that its water temperature of 67 degrees Celsius and examination of water this well was found to contain several elements of metal and sulfur it's very important for the Physiotherapy.

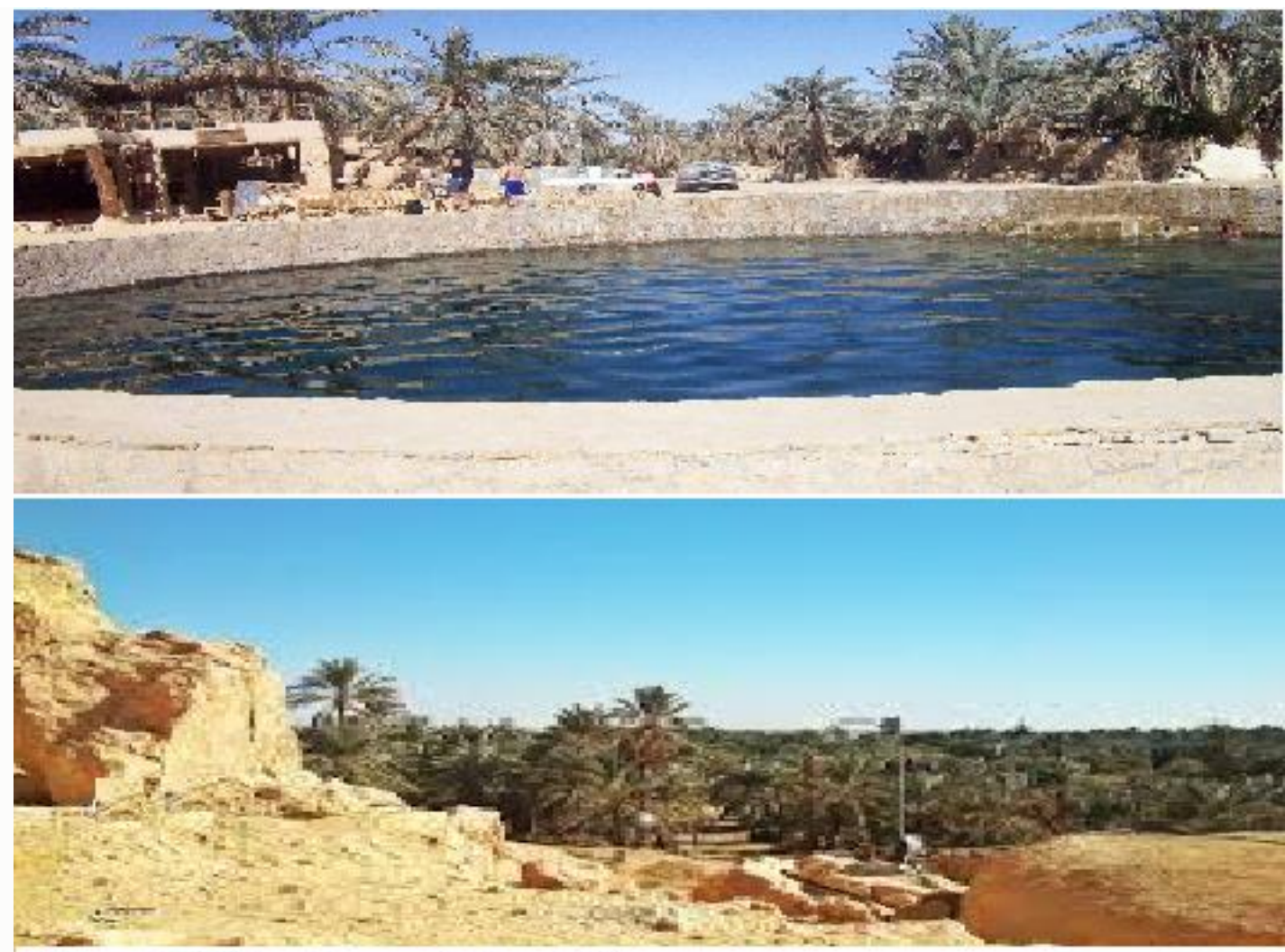

Figure 10: Siwa Eye and Mount Dakror

- Sinai: Sinai Lying in the extraordinary north eastern piece of Egypt, Sinai is formed like a triangle, limited by the Gulf of Aqaba on the eastern side, and the Gulf of Suez on the western side from Sinai, Is the South Sinai zone high portrayed by quiet, low humidity and the presence of the water sulfur appropriate for treatment and fix of numerous maladies and furthermore the hot sand delicate in a few territories which are especially helpful in the treatment of rheumatic sicknesses notwithstanding what is known by the types of numerous herbs and characteristic plants that are utilized in prescription and treatment. There is Sinai a great deal of eyes to water warm like bath Pharaoh site and bathrooms Moses of historical interest as that of the baths the importance of treatment due to the containment of water sulfur, and the unique location on the shore of the Gulf of Suez and the holiness of the territory and its very own from the core of followers of the three monotheistic religions to alike. Sinai Taba Heights Salt Cave is an ongoing man made, the cavern made completely of salt brought from two spots Siwa Oasis and the Dead Sea. Accused of iodine, bromine, magnesium, iron, calcium, sodium and potassium, the salt cavern is the main common recuperating focus in Egypt. The outstanding microclimate made by a roof that has stunning salt stalactites and a story secured with salt gems renews your quality and magnificence while shading plans and lighting structured by shading treatment specialists makes a characteristic quieting of the faculties. one meeting inside the salt cavern is an extraordinary support against sensory system issues, stomach related plot issues, metabolic issues, respiratory issues, dermatological sicknesses and coronary illness. 


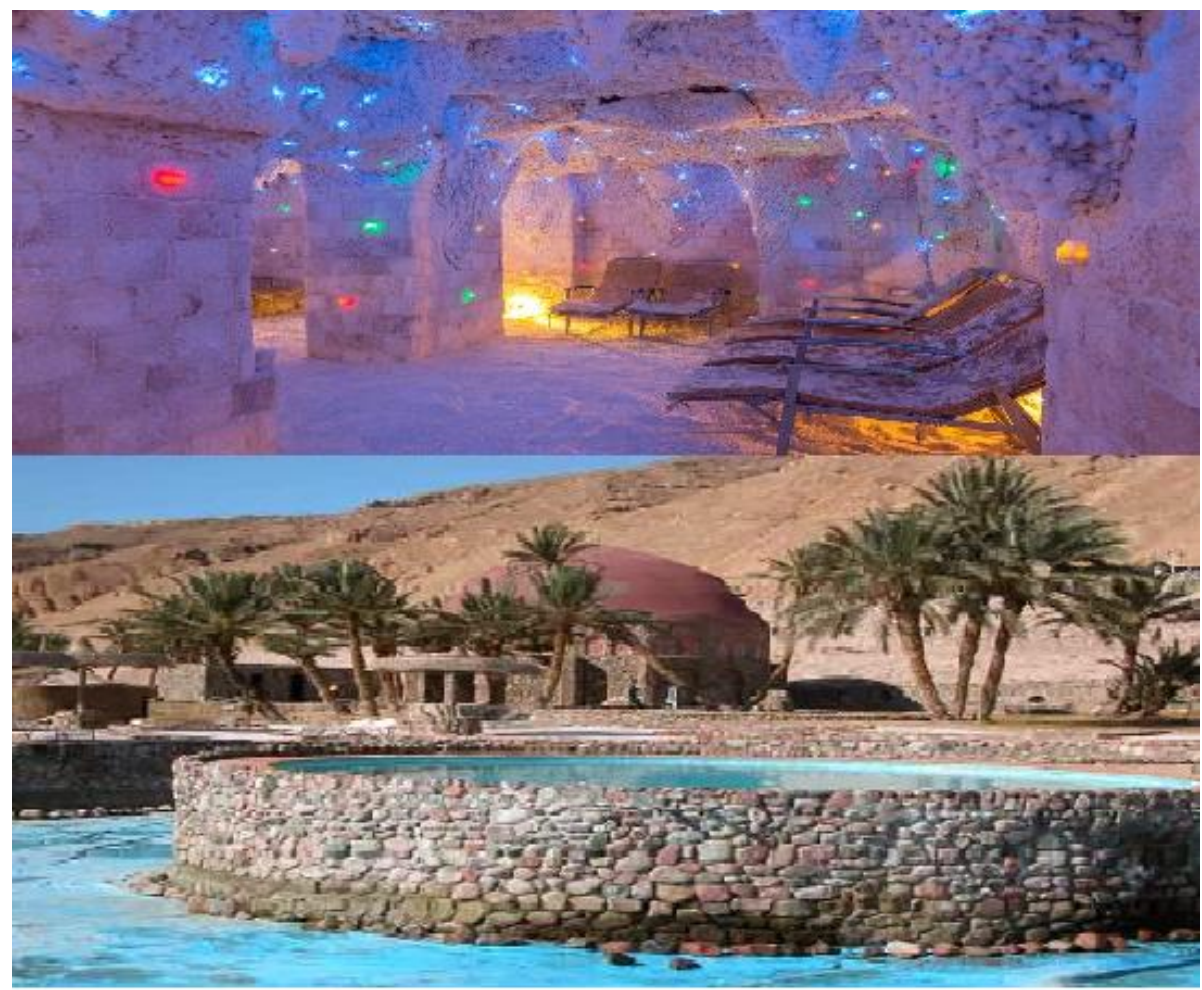

Figure 11 Pharaoh's Bath and Taba Heights Salt Cave

- Helwan Zone: Helwan suburb is found $30 \mathrm{KM}$ from the center of Cairo city and rising from the sea by about 40 meters Helwan has a very dry atmosphere, the humidity does not exceed $58 \%$ in addition to several metal eyes and sulfurous unmatched in the world in terms of the degree of purity and therapeutic interest.

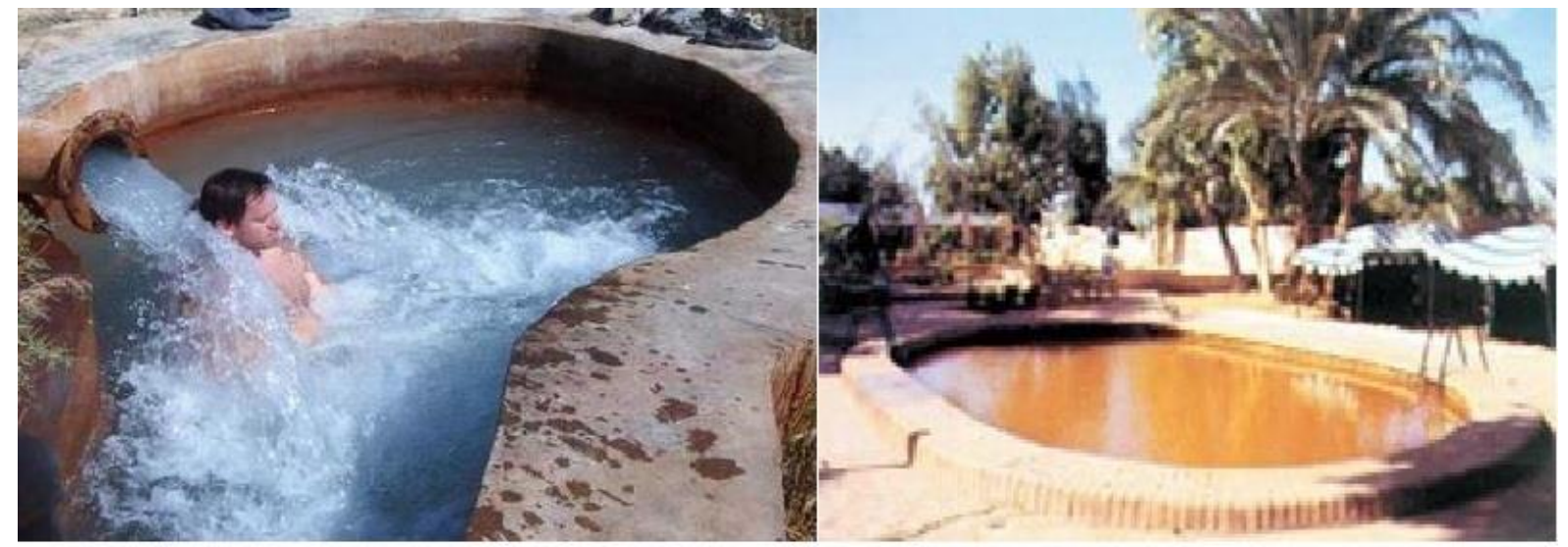

Figure 12-helwan water Eyes

- Bahariya Oasis: Track Bahariya Oasis Giza governorate, situated around 365 kilometers southwest of the city of Giza, and social affair zone to the components of the recorded and archeological the travel industry incredible potential for clinical the travel industry and ecological hospitalization, In Bahariya desert garden around 400 eye mineral water warm and cold and sulfur which have situated to get one of the most significant helpful hotels on the planet for greatness dry mild atmosphere and splendid sun the entire year.
- The new Valley Governorate: The New Valley of the biggest governorates of Egypt and is in the southwestern part of the Egypt. it's occupies approximately $37.6 \%$ of the aggregate zone of Egypt. Its capital is Kharga, within the Kharga Oasis, New Valley and enjoy a pleasant climate throughout the year, is characterized by the drought and the absence of moisture what's more, sunshine always and air purity flawless without air pollutants in urban and densely populated places. The spread in the region, the beautiful soft sand and herbs and medicinal plants, which extracted botanical drugs and aromatic oils. The area is rich in natural as well as eye and wells which rises to a 
temperature of $34 \mathrm{C}$ and contain several great metal items of interest. In New Valley Governorate found the profound wells streaming self, starts in a profundity of 1,000 meters, and temperature of 28 Celsius, encompassed by spreads of greenery.

\section{INFORMATION TECHNOLOGY AND SMART TOURISM}

Egypt the most important and interesting civilizations in history and remains just as interesting as so many of the old structures and monuments still exist. That as well as Egypt has numerous unimaginable shorelines, fantastic beaches, food, and climate. That reasons makes Egypt becoming a travel destination that is very interesting to be visited by many tourists and travelers either both local and international. Every year the number of tourists and travelers who coming to Egypt has more increased and became the tourism industry to be a very important sector for Egyptian economical.

The fast development and advancement of tourism industry area in Egypt must be equilibrated by the evolution and development of technologies and the supported the technology facilities. Presently, the use of a cell phone innovation is one of the important and significant things and a part of modern people daily activities. By taking the upsides of a a new technology innovation, Information Technology has assumed a basic activity in the travel industry business over the span of the latest decade. Innovation and Advancement has diminished costs, upgrade and overhaul operational proficiency, and administrations. Improve tourism services and travelers experience.

Both tourists and tourism organizations can benefit by upgraded communication, operation, reservations, and transportation methods and tourists benefit advantage systems and superseded exorbitant human work with the technologies tools. This diminishes work costs, yet what is more avoids travelers' issues.

The new technologies is smart tourism tools enable tourism decision maker to make smart decisions when using technology into tourism industry and Implement Information and the new Technologies helped to improve quality of Life, personal satisfaction efficiency of effectiveness of portability, economy, manageability and sustainability.

Smart tourism through using a new technology can be defined as the following: "a platform, which is executing information and communication technologies for example Artificial Intelligence, The Global Positioning System, Cloud Computing and Internet of Things to offer the tourism industry information and upgraded tourism services established by smart phones mobile and tablets devices \& end-user devices to make a smart tourism destination the Smart and dynamic connection and association of partners through innovative stages is a key factor. The essential objective of these stages is to make a powerful and integrated information exchange regarding all tourism industry activities (Buhalis \& Amaranggana, 2013).

Here are some examples of new technologies continues to improve the tourism industry.

$>$ Smart Phone and GPS.

$>$ E-tourism, Internet, social media

$>$ Big Data \& Big data Analytics.

$>$ Artificial Intelligence (AI).

$>$ Cloud Computing.

$>$ Internet of Things (IOT).

\section{$>$ Smart phones \& GPS}

Compact tablets and smart cell phones have replaced considerable workstations this is helpful, considering the way that various explorers take a mobile phone with them on a journey. This enables accommodation organizations to keep clients informed with respect to changes and postponements to their reservations, offer arrangements, and publicize by utilizing GPS following and Tourists can simply utilize their cell phones to investigate the destination and information about the sites seeing Users enabled by technology in SMART Tourism Tools are able to navigate their way through countries and cities.

smart phone business successfully helped to arrive at the tourist's complicated needs anyplace whenever to meet the explorers' modern needs, for cases, Web data search, SMS (short message administrations), MMS (interactive media message administration), banking, installment, gaming, messaging, talk, climate gauge, GPS (worldwide situating administration), map, the portable route framework, zone based flexible guide and so forth (Brown and Chalmers, 2003; Li, 2013; Wang et al., 2014).

\section{$>$ E-tourism, Internet, social media:}

The internet has a powerful and affects the tourism business industry. A tourist's first involvement in your business is a visit to your website. This fuse seeing pictures, reviews and audits from past tourists. It is vital for a business to effectively utilize online advertising, social media, blogs, and online booking, and online payment to help comfort their clients, particularly when your rivals from the same field are doing likewise. The significance of the internet and E-commerce is felt and incredibly accentuated in all business field. The E-tourism industry and its utility give a great deal of information on tourism destinations, accommodation places, Transportation, facilities, prices and geographical features and climate. More number of organizations integrated all the services on their portal like the Global Distribution system (Amadeus, Travel Port and Saber) in flight fields in one portal and provides a complete package with a very competitive price to the required clients. Big Data \& Big data Analytics:

Big Data alludes to computerized information volume that Data alludes to advanced digital data volume, speed access and deferent variety that enable novel approaches to frontier questions previously enable novel approaches to frontier questions beforehand inaccessible or impractical utilizing present technologies and methods, additionally 
surpass the limit or storage capacity of current or traditional techniques and methods and systems (National Institute of Standards and methods and systems (National Institute of Standards and Technology 2013 ).

\section{Big Data \& Big data Analytics in tourism industry:}

Tourism industry and the Big Data, at first sight, may not be two fields that seem to have much in common. actually, is that today the tourism industry using the new technologies and benefits from the use of a lot of the technology, to keep developing and enhancing the tourism services performance like reservation in a accommodation and airlines ... etc.

Tourism industry is an information-intensive industry, so the Big Data topic has increased inconceivable fame in broad communications and scientific world. It is a definition amongst the most striking specialized trendy expressions these days (Pries \& Dunnigan 2015, 2). The marvel of Big Data got an incredible reaction in all circles of human interactivities. Big Data is not just the course of the business, yet it speaks to a whole science, fit for gauging the future possibilities. In addition, Big Data is seen as the revolution of the digital era, compared with "novel Energy" in the centrality level for the overall population (Rotella 2012, 1). Just as rough materials, the enormous information amount in an unadulterated structure includes a much lower key knowledge esteem conversely with the creation, got from information the board and analyzing. Big Data is a wellspring of information that carries a great effect into the normal routine life.

Big data brings unlimited opportunities for the tourism business, the abundance of tourism industry big data has the potential to deliver new and more highly informed inferences about people behavior and activity that will give the tourism industry sector area a major lift and benefit tourists and travelers as well as those and the travel agents who participate in the tourism business sector. (Fuchs, Hopken, \& Lexhagen, 2014).

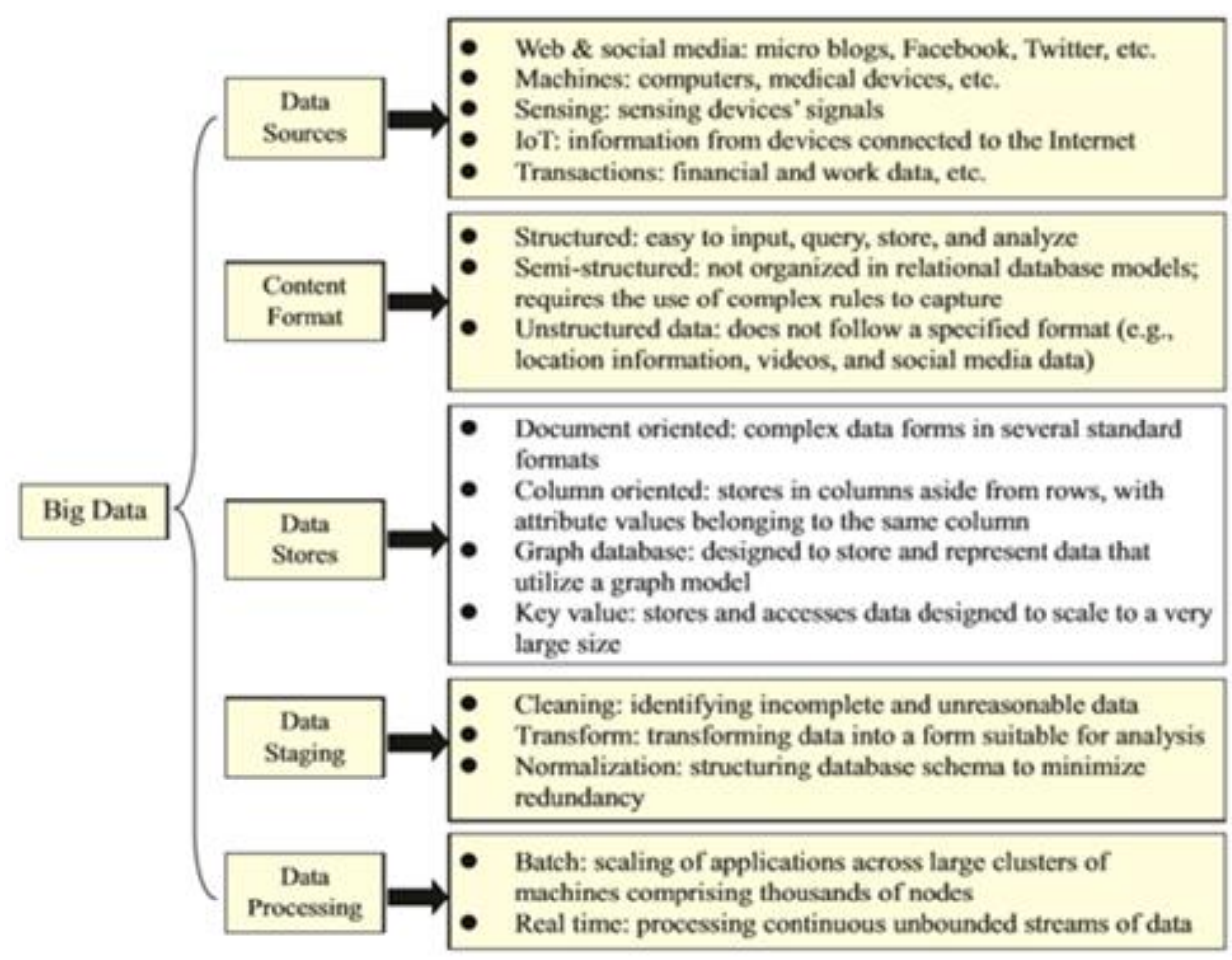

Fiqure 13: Biq Data classification (Hashem et al., 2015 )

\section{> Forecasting Tourist needs Using Big Data:}

The Big Data through proposed portal provides great potential for tourists seeking excursions in decision-making by following and investigate shopping designs, suggestions, buying and behavior.

Travel agents and tour operators by this portal can find inventive approaches to utilize a assortment of data resources to interface with potential tourists' travelers at each phase of the journey and use these Big data sources to understand the tourists needs to forecast tourist's needs and demands in tourism industry and offering the sustainable tourism information and programs in Egypt to develop sustainable tourism in Egypt by increasing the tourist awareness of sustainability and sustainable tourism. Since the new accessibility of electronic information from webbased data sources for example, search engine traffic, tourists feedback on review platforms and web activity, has a natural relation with tourism needs and demands, this big data has been utilized for tourism request forecast (Hopkin, Ernesti, Fuchs,Kronenberg, \& Lexhagen, 2017).

The use of tourists means of modern technology such as smart phone, social media such as Facebook, Twitter, YouTube, Instagram and also technology of things produces huge amounts either through search and planning 
of the trip or through the booking of air and accommodations and transportation and tourist attractions and The Most of this data is of an outer nature: for example, instance, as Twitter, Facebook, Instagram or interpersonal interaction channels and other social networking feeds.

The importance of using big data in the field of tourism: According to Song and Liu (2017) the utilization of tourism business related big data seems to have advantages over traditional methodologies systems. Initially, the dependability of the data is higher since it is a view of tourist ' genuine activities real actions and not on samples which allows us to consider all parts of the information and to think about all parts of the data and to consider all parts of the data in order to provide precise outcomes instead of bad biased conclusions due to a lot of data loss because of the utilize sample of a test data.

Additionally, since the travel industry huge information data is created by tourists themselves, it advances the information on the travel industry organizations' objective markets and is useful for analyzing tourists' needs, demands and requests for tourism products and services for sightseeing, destinations, transportation and accommodations (Hendrik \& Perdana, 2014).

The tourists leave a variety of advanced information behind on the Web when utilizing portable innovations. Through each tourist, a lot of information are accessible about anything that is important to any movement arrange: from his plan, seeking, reservation. Amid and after the vacation trip. (Hendrik \& Perdana, 2014).

\section{Tourism industry Forecasting utilizing Big Data:}

The utilization of Big data in tourism industry forecasting as massive data could bring many benefits to the tourism industry, Tourism administrations organizations, such as the Global Distribution System, are specialized in providing flight booking services, car rental and accommodation booking ... that successfully and viably catch and implement big data strategies gain a competitive advantage since the advancement required to process tremendous data is a snag for some business clients and travel agents by virtue of its unpredictability and cost.

\section{Big data capturing in tourism sector}

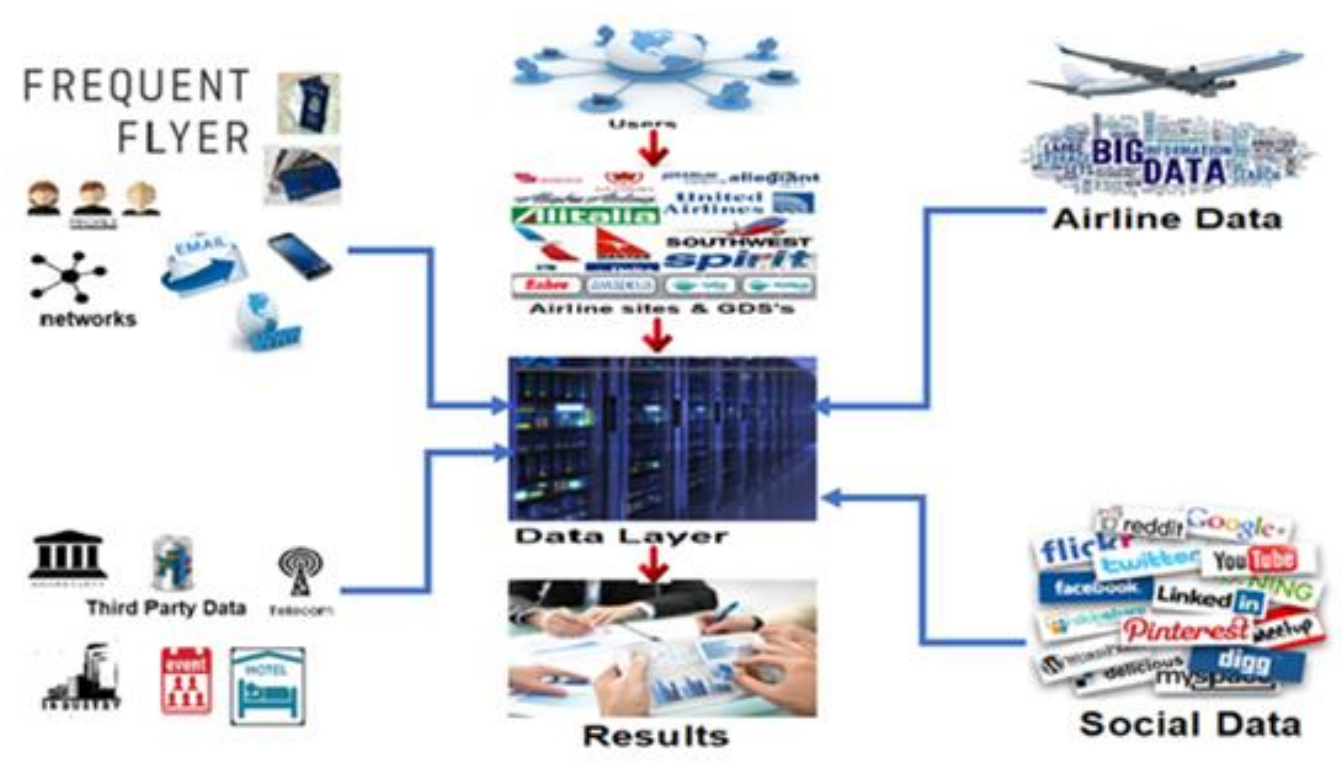

Figure 14-Big data capturing in tourism sector.

There is an extraordinary amount of tourism client and travel agents created content on Egypt standard online travel sites the information incorporate content and photographs in sightseeing websites, yet additionally labeled information, for example, travel dates, travel costs, lengths of remain, related goals, With the promotion of web electronic advances, internet based life, PDAs, GPS and other hand-held processing gadgets the travel industry information assortment has become easier.
Tourists leave lengthy trails of data when they travel. Online booking, purchasing and payment are made online, itineraries are stored in digital calendars, and GPS coordinates are shared every step of the way. Voluminous information is created by different partners, which can't be taken care of with customary information procedures. The Big Data strategies have especially reassuring part and promising element to use such immense information assortment. Big Data is capable to analyze this data from tourist industry and make a prediction for further growth of industry. 
Tourism companies and travel agents now currently can utilize this data to give more focused-on client support, promoting and anticipating the tourist's needs and spread it. And still difficult to access the data in servers of travel companies, but with the transformation into cloud computing, departmental walls break down as data starts to be held in the cloud computing Storages, the colossal information that can be shared through the enterprises and associations.

\section{CONCLUSION}

To answer the problem of forecasting the tourist's needs and develop sustainable tourism in Egypt by increasing the tourist awareness of sustainability and sustainable tourism through using Cloud Computing and Big Data is needed to support a tourism industry in Egypt and to obtain both financial and operational stability, The technological revolution in the tourism industry has led to a growing demand for tourism, marketing and tourism design. Both tourism companies and destinations have been forced to adjust their tourism planning and management strategies so that they can adapt to the new needs of the sector. The Big Data technology enables to process large volumes of data, one of the biggest opportunities of the Big Data is that predictive analyses can be carried in tourist industry, thanks the generation of knowledge acquired after the structured ,semi structured and unstructured data has been processed. The ideal utilization of huge information for gauging and dynamic utilizing legitimate methodologies and techniques is the most ideal approach to underwrite the benefits of the benefits of big data.

Big Data and data analytics are changing the hypothesis and practice of the travel industry and utilizing these advancements to envision client needs, revamp how they meet client desires by the shrewd the travel industry programs covering the traveler need, reclassify client commitment, and achieve new levels of customer satisfaction.

And offering the sustainable tourism programs, the preferences of tourists and their needs and guiding them towards sustainable tourism of all kinds

To development the health tourism in Egypt should obtain the showcasing ability expected and marketing expertise needed to products and identify target markets. Travel agents are seeking to capitalize on these flows and are linking medical care with actual tourist activities. This business linkage among healthcare and tourism industry is a quickly developing and gainful industry that is attracting growing interest amongst healthcare researchers and analysts, but Research and evaluation has not kept pace with the development of healthcare tourism industry in Egypt.

\section{REFERENCES}

[1]. Ahwireng-Obeng, F., \& van Loggerenberg, C. (2011). Africa's middle-class women bring entrepreneurial opportunities in breast care medical tourism to South Africa. Int J Health Plann Manage, 26(1), 39-55. doi: 10.1002/hpm.1034

[2]. Boes, K., Buhalis, D., \& Inversini, A. (2015). Conceptualizing smart tourism destination dimensions. In Information and Communication Technologies in Tourism 2015 (pp. 391-403). Springer International Publishing.

[3]. Brown, B., \& Chalmers, M. (2003). Tourism and mobile technology. In ECSCW 2003 (pp. 335354

[4]. Buhalis, D., \& Amaranggana, A. (2013). Smart tourism destinations. In Information and Communication Technologies in Tourism 2014 (pp. 553-564). Springer International Publishing.

[5]. Desai, P.R., Desai, P.N., Ajmera, K.D., Mehta, K. (2014): A review paper on oculus rift-a virtual. Int. J. Eng. Trends Technol. (IJETT) 13(4), 175-179.

[6]. Fuchs, M., Hopkin, W., \& Lex Hagen, M. (2014). Big data analytics for knowledge generation in tourism destinations-A case from Sweden. Journal of Destination Marketing and Management, 3(4), 198209.

[7]. Go2hr.ca. (2016). What is Tourism? - BC Tourism Industry - go2HR. [online] Available at: https://www.go2hr.ca/bc-tourism-industry/whattourism [Accessed 27 Dec. 2016].

[8]. Hashem, I. A. T., Yaqoob, I., Anuar, N. B., Mokhtar, S., Gani, A., \& Ullah Khan, S. (2015). The rise of "big data" on cloud computing: Review and open research issues. Information Systems, 47, 98-115.

[9]. Hendrik, H., \& Perdana, D. H. F. (2014). Trip guidance: A linked data based mobile tourists guide. Advanced Science Letters, 20(1), 75-79.

[10]. Hopkin, W., Ernesti, D., Fuchs, M., Kronenberg, K., \& Lexhagen, M. (2017). Big Data as Input for Predicting Tourist Arrivals. In R. Schegg, \& B. Stangl, Information and Communication Technologies in Tourism 2017 (pp. 187-199). Cham: Springer International Publishing AG 2017.

[11]. Huang, Y.-C., Backman, S.J., Backman, K.F. (2012): Exploring the impacts of involvement and flow experiences in second life on people's travel intentions. J. Hospitality Tourism Technol. 3(1), 4-23.

[12]. Kajzar, P. (2015). SELECTED DESTINATIONS FOR HEALTH AND WELLNESS TOURISM IN EUROPE. MASARYK UNIVERSITY FACULTY OF ECONOMICS AND ADMINISTRATION DEPARTMENT OF REGIONAL ECONOMICS AND ADMINISTRATION, $18 \mathrm{TH}$ INTERNATIONAL COLLOQUIUM ON REGIONAL SCIENCES (Histolene, June 17-19, 2015). doi: 10.5817/CZ.MUNI.P210-7861-2015-94

[13]. L. Li, W. Wan, and H. Wei, "The analysis of environmental impact on desert tourism resources exploration," in Proc. 2011 International Conference on Remote Sensing, Environment and Transportation Engineering (RSETE), June 2011, pp. 1754-1756. 
[14]. Li, W. (2013). Dimensions of Trust in Tourism Mcommerce: a Conceptual Model. Information Technology Journal, 12(15), 3279.

[15]. Neuhofer, B., Buhalis, D., Ladkin, A. (2012): Conceptualizing technology enhanced destination experiences. J. Destination Mark. Manage. 1(1-2), 36-46.

[16]. Pries K., Dunnigan R., 2015. Big Data Analytics: A Practical Guide for Managers, Taylor \& Francis Group, LLC, CRC Press, p. 2

[17]. Rotella P., 2012. Is Data The New Oil? [web publication] Forbes Tech [accessed 28 April 2016].

[18]. Scowsill, D., 2017. Global Economic Impact \& Issues 2017. Economic impact research. World Travel \& Tourism Council. Retrieved June 9, 2017 from https://www.wttc.org//media/files/reports/economicimpact-research/2017documents/global-economicimpact-and-issues2017.pdf - last accessed 01-09-2018

[19]. Song, H., \& Liu, H. (2017). Predicting Tourist Demand Using Big Data. In Z. Xiang, \& D. Fresenmaier, Analytics in Smart Tourism Design (pp. 13-29). Cham: Springer International Publishing Switzerland 2017.

[20]. The world bank https://data.worldbank.org/indicator/ST.INT.RCPT.C D

[21]. Tussyadiah, I.P., Wang, D., Jia, C.H. (2017): Virtual reality and attitudes toward tourism destinations. In R. Schegg, B. Stangl (eds.) Information and Communication Technologies in Tourism (Springer), 217-228.

[22]. Wang, L., Law, R., Hung, K., \& Guillet, B. D. (2014). Consumer trust in tourism and hospitality: A review of the literature. Journal of Hospitality and Tourism Management, 21, 1-9.

[23]. World Tourism Organization (UNWTO) UNWTO Tourism Highlights, 2017 Edition International Monetary Fund (IMF) www.imf.org/en/publications/weo last accessed 0205-2020 